\title{
Improving Anaerobic Capacity using Speed Agility and Quickness Training
}

\author{
N.W Kusnanik \\ Universitas Negeri Surabaya \\ Surabaya, Indonesia \\ niningwidyah@unesa.ac.id
}

\author{
K. Azmi \\ Sekolah Tinggi Ilmu Tarbiyah Nahdlatul Ulama Al Mahsuni \\ Lombok Timur, Indonesia \\ khairulazmimpd@gmail.com
}

\author{
S.P. Bird \\ University of Charles Sturt \\ Bathurst New South Wales, Australia \\ spb@stephenbird.co
}

\begin{abstract}
The main purpose of this study was to evaluate the effect of speed agility and quickness (SAQ) training in improving anaerobic capacity. This research was conducted at 26 male soccer sub elite players and divided into 2 groups with 13 players each groups. Group 1 was given SAQ training program, Group 2 conventional training program during 6 weeks training period with 3 times per week. This research was quantitative with matching only design. Data was taken from pretest and posttest of anaerobic testing: vertical jump, standing broad jump, and $40 \mathrm{~m}$ sprints. The research data was analyzed using statistical analysis paired $t$ test and independent $t$ test. The result showed that there was significant effect of SAQ training in improving anaerobic capacity (vertical jump, standing broad jump, $40 \mathrm{~m}$ sprint) with $p<0.05$. It can be concluded that SAQ training program can be used to improve anaerobic capacity.
\end{abstract}

Keywords-anaerobic capacity; speed agility quickness; vertical jump; standing broad jump; fourty sprint

\section{INTRODUCTION}

Improving high achievement of athletes in many sports is necessary to give special attention to determinant of success. One of the important things in achieving of achievement in sports is physical condition. There are four factors to achieve the achievement in sports including physical, technical, tactical, and mental preparation. Physical preparation is very important to improve the functional potential of athletes and to develop the ability of physical condition in order to achieve the highest standard. There are some components of physical condition that are needed in sports such as speed, strength, power, agility, flexibility, and endurance. Increasing aspects of physical conditions such as speed and strength are very important to get muscle power (muscle power output) and athlete's most important abilities to success in sports [1]. Vertical jump test and running speed have become the most popular tests that are used to evaluate lower body strength. Anaerobic capacity is defined as the maximum amount of adenosine triphosphate synthesized again through anaerobic metabolism (by all organisms) during the specific mode of maximum short duration exercise [2].
The ability to jump such as standing broad jump and vertical jump has become a convenience as a tool that is needed by sports experts to measure the abilities of physical condition's athletes [3]. Standing broad jump is one of the physical fitness tests or motor skills whose performance is often regarded as strength index [4]. Standing broad jump is a test commonly used to assess leg power. Because of its simple and time efficient implementation that does not require any equipment, this is routinely used by trainers from several sports for talent selection, measurement, and prediction of anaerobic power [5]. Standing broad jumps are usually used in athlete training various sports. Furthermore, this exercise/test represents an explosive type of movement, which correlates well with other types of explosive movement such as the vertical jump and sprinting [6]. Athletes who have both power and legs strength will be able to move and jump forward farther and higher. Speed is one of the basic components that are necessary in some sports. Every sporting activity, whether it is a game, race or match, always requires speed component. Speed is a complex ability, because in general, speed is an ability that allows a basketball player to move as fast as possible at a certain level of resistance [7].

Speed, agility, and quickness can be trained the complete spectrum of training intensity such as low, medium, and high intensity. Each athlete has a different level, thus, the intensity of the exercise must coincide with the individual's abilities. SAQ exercises can also be used to teach movements such as warming up or to improve the athlete's physical condition [8]. Speed, agility, and quickness are training methods that can be used to develop motor skills and controlling body movements through the development of the neuromuscular system. In addition, it can be used to improve the ability of athletes to carry out multi-directional motion explosives by reprogramming the neuromuscular system, so that they can work more efficiently [9]. Speed, agility, and quickness training method have become a popular way to train athletes. Training of speed, agility, and quickness is a system of progressive exercise and instruction that are used to develop fundamental motor skills to improve the ability of the athletes' skills with faster speed and greater precision. In addition, 
speed, agility, and quickness training method can be used to improve the speed, strength, or the ability to exert maximum force during movement activity at high speed. Therefore, the purpose of this study is to improve anaerobic capacity by using speed, agility, and quickness training method.

\section{METHODS}

Type of this research is quantitative with quasiexperimental methods using matching only design. This research was conducted at 26 male soccer sub elite players and divided into 2 groups with 13 players each groups. Group 1 was given SAQ training program by Bujjibabu, Group 2 conventional training program during 6 weeks training period with 3 times per week. Data was taken from pretest and posttest of anaerobic testing. Instruments of the research were vertical jump, standing broad jump, and 40m running sprint. The research data was analyzed using statistical analysis paired T-test and independent T-test.

\section{RESULTS AND DISCUSSION}

The results of the study were presented in Table 1, Table 2, and Table 3.

TABLE I. DATA PRE-TEST AND POST-TEST OF GROUP 1 (SAQ TRAINING)

\begin{tabular}{|l|c|c|c|c|c|c|}
\hline \multirow{2}{*}{ Average } & \multicolumn{2}{|c|}{ Vertical Jump } & \multicolumn{2}{c|}{$\begin{array}{c}\text { Standing Broad } \\
\text { Jump }\end{array}$} & \multicolumn{2}{c|}{ 40 meters Sprint } \\
\cline { 2 - 7 } & $\begin{array}{c}\text { Pre- } \\
\text { test }\end{array}$ & $\begin{array}{c}\text { Post- } \\
\text { test }\end{array}$ & $\begin{array}{c}\text { Pre- } \\
\text { test }\end{array}$ & $\begin{array}{c}\text { Post- } \\
\text { test }\end{array}$ & $\begin{array}{c}\text { Pre- } \\
\text { test }\end{array}$ & $\begin{array}{c}\text { Post- } \\
\text { test }\end{array}$ \\
\cline { 2 - 7 } & 49.08 & 55.15 & 212.46 & 223.77 & 5.83 & 5.38 \\
\hline $\begin{array}{l}\text { Standard } \\
\text { Deviation }\end{array}$ & \multicolumn{2}{|c|}{2.98501} & \multicolumn{2}{|c|}{12.73044} & \multicolumn{2}{|c|}{0.40503} \\
\hline Increase & \multicolumn{2}{|c|}{$12 \%$} & \multicolumn{2}{|c|}{$5 \%$} & \multicolumn{2}{|c|}{$8 \%$} \\
\hline
\end{tabular}

As can be seen from Table 1, the anaerobic capacity (vertical jump, standing broad jump, and 40m sprint) improved after being given SAQ training program. Vertical jump was approximately $6.07 \mathrm{~cm}$ or $12 \%$ improved. In addition, standing broad jump was $11.31 \mathrm{~cm}$ or $5 \%$ increased. Furthermore, $40 \mathrm{~m}$ sprints also improved about 0.45 seconds or $8 \%$.

TABLE II. DATA PRE-TEST AND POST-TEST OF GROUP 2 (CONTROL GROUP)

\begin{tabular}{|l|c|c|c|c|c|c|}
\hline \multirow{2}{*}{ Average } & \multicolumn{2}{|c|}{ Vertical Jump } & \multicolumn{2}{c|}{$\begin{array}{c}\text { Standing Broad } \\
\text { Jump }\end{array}$} & \multicolumn{2}{c|}{ 40 meters Sprint } \\
\cline { 2 - 7 } & $\begin{array}{c}\text { Pre- } \\
\text { test }\end{array}$ & $\begin{array}{c}\text { Post- } \\
\text { test }\end{array}$ & $\begin{array}{c}\text { Pre- } \\
\text { test }\end{array}$ & $\begin{array}{c}\text { Post- } \\
\text { test }\end{array}$ & $\begin{array}{c}\text { Pre- } \\
\text { test }\end{array}$ & $\begin{array}{c}\text { Post- } \\
\text { test }\end{array}$ \\
\cline { 2 - 7 } & 50.00 & 51.92 & 205.92 & 212.85 & 5.94 & 5.64 \\
\hline $\begin{array}{l}\text { Standard } \\
\text { Deviation }\end{array}$ & \multicolumn{2}{|c|}{2.56455} & \multicolumn{2}{|c|}{8.39108} & \multicolumn{2}{|c|}{0.47689} \\
\hline Increase & \multicolumn{2}{|c|}{$4 \%$} & \multicolumn{2}{|c|}{$3 \%$} & \multicolumn{2}{|c|}{$5 \%$} \\
\hline
\end{tabular}

Table 2 indicated that there were slightly increased in anaerobic capacity of the control group. Vertical jump improved approximately $1.92 \mathrm{~cm}$ or $4 \%$ and standing broad jump increased $6.93 \mathrm{~cm}$ or $3 \%$. $40 \mathrm{~m}$ sprints were also improved 0.3 seconds or $5 \%$.
TABLE III RESULTS OF ANALYSIS OF THE INDEPENDENT SAMPLES TEST

\begin{tabular}{|c|c|c|c|}
\hline \multicolumn{2}{|c|}{ Test Component } & \multirow{2}{*}{$\begin{array}{l}\mathrm{T} \\
-0.604\end{array}$} & \multirow{2}{*}{$\begin{array}{l}\text { Sig. (2-tailed) } \\
0.552\end{array}$} \\
\hline Pre-test & Equal variances assumed & & \\
\hline & $\begin{array}{l}\text { Equal variances not } \\
\text { assumed }\end{array}$ & -0.604 & 0.552 \\
\hline \multirow{2}{*}{$\begin{array}{l}\text { Pre-test } \\
\text { Standing Broad } \\
\text { Jump }\end{array}$} & Equal variances assumed & 1091 & 0.286 \\
\hline & $\begin{array}{l}\begin{array}{l}\text { Equal variances } \\
\text { assumed }\end{array} \\
\text { not }\end{array}$ & 1091 & 0.286 \\
\hline \multirow{2}{*}{$\begin{array}{l}\text { Pre-test } \quad 40 \\
\text { meters Sprint }\end{array}$} & Equal variances assumed & -0.604 & 0.552 \\
\hline & $\begin{array}{l}\text { Equal variances not } \\
\text { assumed }\end{array}$ & -0.604 & 0.552 \\
\hline \multirow{2}{*}{$\begin{array}{l}\text { Post-test } \\
\text { Vertical Jump }\end{array}$} & Equal variances assumed & 2.174 & 0.40 \\
\hline & $\begin{array}{l}\text { Equal variances not } \\
\text { assumed }\end{array}$ & 2.174 & 0.40 \\
\hline \multirow{2}{*}{$\begin{array}{l}\text { Post-test } \\
\text { Standing Broad } \\
\text { Jump }\end{array}$} & Equal variances assumed & 2.136 & 0.43 \\
\hline & $\begin{array}{lll}\begin{array}{l}\text { Equal variances } \\
\text { assumed }\end{array} & & \text { not }\end{array}$ & 2.136 & 0.43 \\
\hline \multirow{2}{*}{$\begin{array}{l}\text { Post-test } \quad 40 \\
\text { meters Sprint }\end{array}$} & Equal variances assumed & -2.166 & 0.40 \\
\hline & $\begin{array}{l}\text { Equal variances not } \\
\text { assumed }\end{array}$ & -2.166 & 0.41 \\
\hline
\end{tabular}

Table 3 shows that there were no differences between vertical jump, standing broad jump, and $40 \mathrm{~m}$ sprint of the two groups with $\mathrm{P}>0.05$ for the pretest at both groups. In addition, there was significant difference of anaerobic capacity (vertical jump, standing broad jump, and 40m sprints between Group 1 and Group 2 for posttest with $\mathrm{P}<0.05$. It meant that there was significant difference between Group 1 and Group 2. Therefore, there was significant improved of SAQ training program in improving anaerobic capacity.

The results of this study are similar to previous studies conducted by Jovanovic, Sporis, Omrcen, and Fiorentini [10] that SAQ training methods significantly improve the performance of soccer players. In addition, SAQ training has a significant influence on physical fitness variables, including speed, agility, reaction time, power, and flexibility of cricket athletes [11].

Tests of anaerobic capacity can be classified according to whether they are quantifying capacity, or providing a work estimate of anaerobic capacity. This review focuses on the former tests with particular emphasis on both maximal blood lactate, because of its widespread use but controversial, and the oxygen deficit, because of its recent popularity within applied and theoretical sports physiology. The measures of debt are also evaluated, and the comparative utility of all measures (such as oxygen deficit, oxygen debt and maximum blood lactate) are assessed [12]. 
This study is also supported by Milanovic's research [13] that speed, agility, the strength of the impact of speed, agility, and quickness (SAQ) training as part of the overall training process, can be considered as a useful tool for fix physical condition between young soccer players. In addition that speed agility and quickness training can improve athletes' physical condition, especially in the components of speed, agility and acceleration [14]. Exercise of speed, agility, and quickness training methods can provide a very specific and detailed that will help athletes to support the best performance in sports. In addition, training in speed, agility, and quickness has a variety of varied exercises so that when the coaches give the training program of speed, agility, and quickness athletes will not be bored to take part in training activities.

\section{CONCLUSION}

Based on the results of the research and discussion previously described, it can be concluded that there is a significant effect on the agility, speed and quickness training program in improving anaerobic capacity.

\section{ACKNOWLEDGMENT}

Authors would like to thank you to PNBP Unesa for supporting to attend and present the manuscript at SOSHEC 2019.

\section{REFERENCES}

[1] D.V. Eduadosaez, R. Bernardo, I. Mikel, and J. Juan, "Enhancing sprin and strenght performance: combined versus maximal power, traditional heavy-resistance and plyometric training", Journal of Science and Medicine in Sport, (16), pp.146-150, 2013.

[2] G. Simon, and D. Brian, "measurement of anaerobic capacities in humans”, Sports Medicine, 15 (5), pp.312-327, 1993.

[3] S. Khalid, Almuzaini, and J.F. Steven, "modification of the standing broad jump test enhances ability to predict anaerobic performance", Journal of Strength and Conditioning, Vol. 22, No. 4, July 2008.
[4] M. Kokubun, "The relationship between the effect of setting a goal on standing broad jump performance and behaviour regulation ability in children with intellectual disability", Journal of Intellectual Disability Research, Vol. 43, part 1, 1999.

[5] A. Krishnan, D. Sharma, M. Bhatt, A. Dixit, and P. Pradeep, "Comparison between standing broad jump test and wingate test for assessing lower limb anaerobic power in elite sportsmen", Medical Journal Armed Forces India, 73(2), pp.140-145, 2017

[6] J. Alexander, K.S. Koch, S.O Harold, P. Christopher, S. Elizabeth, E.S Margaret, H. Joe, and B. Rhonda, "Effect of warm-up on the standing broad jumpin trained and untrained men and women", Journal of Strength and Conditioning Research, 17(4), pp.710-714, 2003.

[7] Jakovljevic, "The level of speed and agility of different types of elite female basketball players," Facta universitatis-series: Physical Education and Sport, Vol. 9, Issue. 3, 2011.

[8] S. Sharma, and M.S. Dhapola, "Effect of Speed, Agility, Quickness (SAQ) training program on selected physical fitness variables and performance ability in basketball university players", International Educational E-Journal Quarterly, 4(3), pp.14-22, 2015.

[9] V. Vallimurugan, and J.P. Vincent, "Effect of SAQ training on selected physical fitness parameters of men football players," International Journal of Advanced and Innovation Research, Vol. 1, Issue 2, 2012.

[10] M. Jovanovic, G. Sporis, D. Omrcen, and F. Fiorentini, "effect of speed, agility, and quickness training method on power performance in elite soccer players", Journal of Strength and Conditioning Research, Vol. 25, May 2011.

[11] R. Kumar P, and M. S. Dhapola, "Effect of eight weeks s.a.q. training programme on selected physical fitness variables," International Multidisciplinary Research Journal, Vol. 3, Issue 7, ISSN No. 22315063, 2014

[12] S. Green, and B. Dawson, "Measurement of anaerobic capacities in humans," Sports Medicine, 15 (5), pp.312-327, 1993

[13] Z. Milanovic, G. Sporis, N. Trajkovic, N. James, and K. Samija, "Effect Of A 12-Week SAQ Training Programme On Agility With And Without The Ball Among Young Soccer Players," Journal Of Sport Science And Medicine, 12, pp. 97-103, 2013.

[14] K. Azmi, and N.W. Kusnanik, "Effect of exercise program Speed, Agility, and Quickness (SAQ) in improving speed, agility, and acceleration", IOP Conf. Series: Journal of Physics: Conf. Series $947-$ 012043,2018 